\title{
Testing the Use of the Water Milfoil (Myriophyllum spicatum L.) in Laboratory Toxicity Assays
}

\author{
David Sánchez $\cdot$ Manuel A. S. Graça $\cdot$ Jorge Canhoto
}

Received: 11 January 2007 / Accepted: 16 March 2007/Published online: 11 May 2007

(C) Springer Science+Business Media, LLC 2007

\begin{abstract}
Tests aiming to determine the toxic properties of compounds discharged into aquatic systems have relied more on fish or invertebrates than on primary producers and among a number of producers; algae are the most popular test organisms. Macrophytes are important ecological elements in freshwaters and are therefore potentially key organisms for use in toxicity testing of compounds suspected of acting in primary producers. The most common macrophyte used in toxicity testing is Lemna sp., but as a floating plant, it has the limitation of being exposed to toxic compounds only through its lower leaf surface, including roots and rhizoids. Therefore, it is questionable whether tests with Lemna may accurately predict potential effects on submersed and exposed plant species, which have different routs of exposure and morphology. Few other submersed macrophytes have been tested, notably Myriophyllum.

In the Iberian peninsula M. spicatum is the most common species within its genus and has been presented as a good bioaccumulator of heavy metals (Wang et al. 1996) and as being sensitive to several toxicants (e.g. Hanson et al. 2003). The aim of this study was to assess the potential of $M$. spicatum as a testing organism in laboratory assays, by obtaining axenic cultures of this plant and exposing them to several reference compounds to determine the sensitive endpoints.
\end{abstract}

D. Sánchez · M. A. S. Graça ( $₫)$

IMAR, Departament of Zoology, University of Coimbra,

3004517 Coimbra, Portugal

e-mail: mgraca@ci.uc.pt

D. Sánchez · J. Canhoto

IAV, Departament of Botany, University of Coimbra,

3004517 Coimbra, Portugal

\section{Materials and Methods}

Stems of M. spicatum were collected from the relatively pristine Carreiras River, in the Guadiana basin, South Portugal, and were kept in outdoor tanks at the University of Coimbra. To obtain axenic cultures, we followed the modified general procedure described in the American Society for Testing and Materials E1913-97 guide for M. sibiricum (2000). Plants were rinsed in deionized water and nodal segments were disinfected in a $3 \%(\mathrm{w} / \mathrm{v})$ sodium or calcium hypochlorite solution containing $0.01 \%$ Tween-20 for periods of 20 minutes for three consecutive days. Between sterilization periods, plants were maintained in the dark under agitation $(60$ rpm) in Andrews modified medium (Selim et al. 1989, in ASTM 2000) with 3\% sucrose. Apical segments of $3 \mathrm{~cm}$ were cut, weighed (fresh mass $\pm 0.001 \mathrm{~g}$ ) and the number of nodes counted. Plant segments were inoculated into $200 \mathrm{ml}$ of sterile Andrew media containing the testing compound in the conditions described by Ferreira and Graça (2002; Table 1).

The following compounds were tested: calcium, iron and copper sulphates, glyphosate and a mining effluent. The sulphates were chosen because of their high concentrations in the tested effluent and other mine effluents (e.g. Coimbra et al. 1996). Copper sulphate has also been related to mining and industrial pollution and the effect of copper on macrophytes and other plants is well documented (Guilizzoni 1991; Roshon et al. 1999). Glyphosate (Nphosphonomethylglycine), a non-selective post-emergent herbicide was tested as its major formulation, Roundup ${ }^{\circledR}$, in which glyphosate is included as a isopropylamine salt and polyoxyethylene amine is present as a surfactant (Tsui $\&$ Chu 2003). We also tested a mine effluent with a low content of heavy metals, but high conductivity, sulphate 
Table 1 Summary of the culture conditions for tests on macrophyte Myriophyllum spicatum

\begin{tabular}{ll}
\hline Agitation & Constant, $100 \mathrm{rpm}$ \\
Temperature & $25^{\circ} \mathrm{C}$ \\
Photoperiod & $14 \mathrm{~h}$ light:10h darkness. $96 \mu \mathrm{m} \mathrm{m}^{-2} \mathrm{~s}^{-1}$ \\
Test chamber & $250 \mathrm{ml}$ Erlenmeyer \\
Test volume & $200 \mathrm{ml}$ \\
Initial organisms size & $3 \mathrm{~cm}$ apical shoots \\
Replicates & 5 \\
Control and culture media & Andrews modified medium \\
Test duration & 21 days \\
Endpoints & Fresh weight, shoot length, node \\
& number, root length \\
\hline
\end{tabular}

Table 2 Concentrations used for four tested compounds and one industrial effluent

\begin{tabular}{ll}
\hline Compound tested & Concentration $(\mathrm{mg} / 1$ or $\%)$ \\
\hline $\mathrm{CaSO}_{4} .2 \mathrm{H}_{2} \mathrm{O}$ & $10000 ; 5000 ; 2500 ; 1250 ; 600 ; 300 ; 150 ; 70 ; 35$ \\
$\mathrm{FeSO}_{4} .7 \mathrm{H}_{2} \mathrm{O}$ & $2500 ; 1250 ; 600 ; 300 ; 150 ; 110 ; 70 ; 45 ; 25$ \\
$\mathrm{CuSO}_{4} .5 \mathrm{H}_{2} \mathrm{O}$ & $40 ; 20 ; 10 ; 5 ; 2.5 ; 1.8 ; 1.2 ; 0.6$ \\
Glyphosate & $80 ; 40 ; 20 ; 10 ; 5 ; 2.5 ; 1 ; 0.5 ; 0.25$ \\
Mining effluent & $5 \% ; 10 \% ; 20 \% ; 40 \% ; 60 \% ; 80 \%$ \\
\hline
\end{tabular}

and nitrate levels, and high $\mathrm{pH}$ (see Ferreira and Graça 2002).

The media was changed weekly only in the case of the effluent. Concentrations for each tested compound were established from the literature and previous experiments and are summarized in Table 2. After 21 days, plants were measured for final plant length, node number (except calcium sulphate), fresh mass and root length. The concentration that inhibited $50 \%$ of the parameter $\left(\mathrm{IC}_{50}\right)$ and the percentage of inhibition (\% I) were calculated according to American Society for Testing and Materials procedures (2000; E 1913 - 97 procedures). Square root, logarithmic or reciprocal transformations were used where appropriated to guarantee the highest correlation using a linear model.

\section{Results and Discussion}

In control conditions, M. spicatum grew $0.019 \mathrm{~g} / \mathrm{day}$ or $0.79 \mathrm{~cm} /$ day, which corresponds to an increase of $29 \%$ in mass and $26 \%$ in length. Under control conditions, all specimens developed roots $(n=1-8)$ with a total length of $17.8 \mathrm{~cm}$ (range 11.8 to $33.8 \mathrm{~cm}$ ).

Calcium sulphate stimulated root growth of M. spicatum in concentrations ranging from 0.07 to $0.60 \mathrm{~g} / \mathrm{l}$; concen-

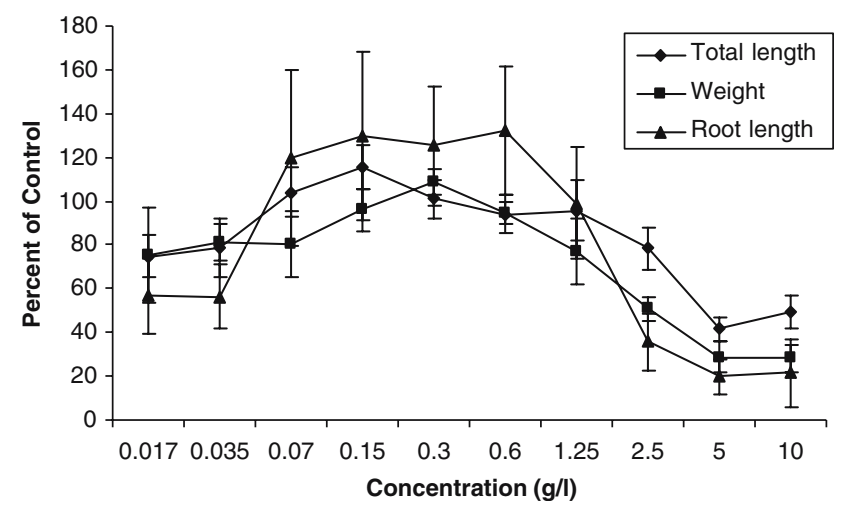

Fig. 1 Total length, weight and root length of M. spicatum after 21 days culture with calcium sulphate. Mean and SE; $n=5$

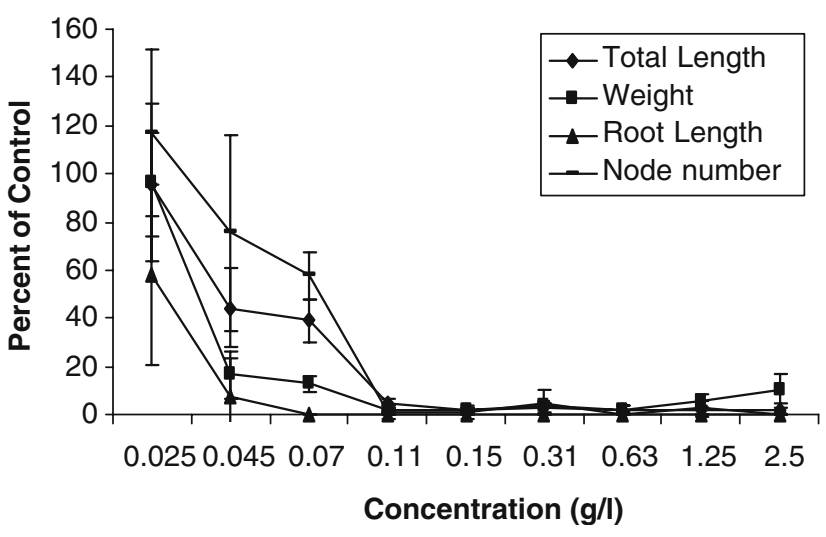

Fig. 2 Plant and root length, weight, and node number of $M$. spicatum after 21 days culture exposed to iron sulphate. Mean and SE; $n=5$

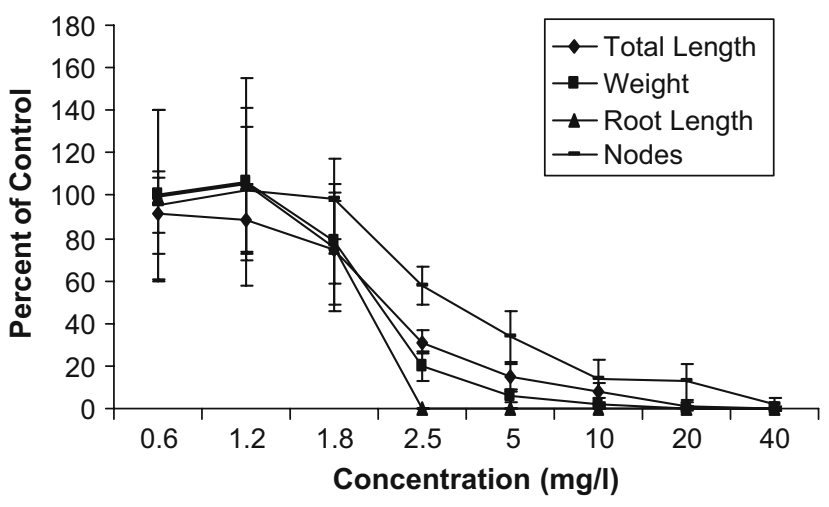

Fig. 3 Total length, weight, number of nodes and root length of $M$. spicatum after 21 days culture with copper sulphate. Mean and SE; $n$ $=5$

trations of $0.6 \mathrm{~g} / \mathrm{l}$ inhibited weight increase while concentrations of $1.25 \mathrm{~g} / \mathrm{l}$ and higher inhibited length and root growth (Fig. 1).

Iron sulphate was more toxic for M. spicatum than calcium sulphate, affecting total length, weight and node 


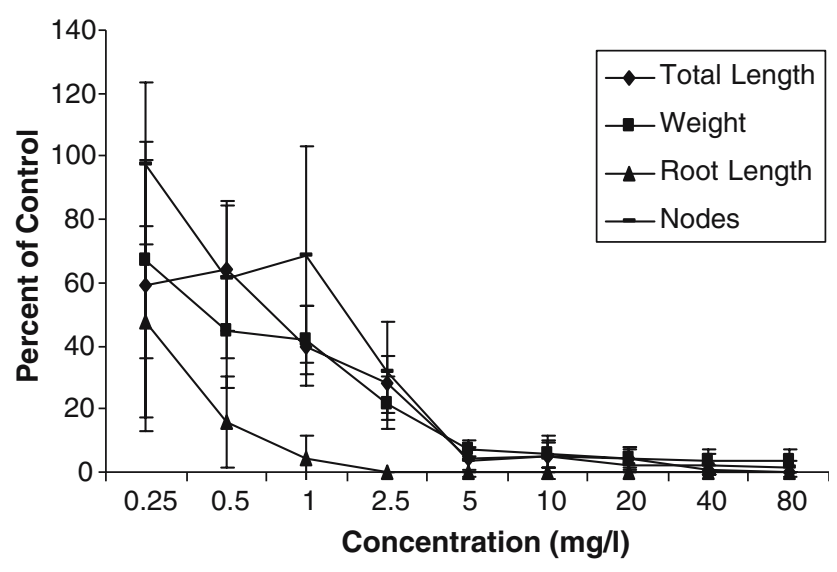

Fig. 4 Total length, weight, root length and node number of M.spicatum after 21 days culture in glyphosate. Mean and SE; $n=5$

number at concentrations of $0.045 \mathrm{~g} / \mathrm{l}$. Root length was already inhibited by the lowest test concentration $(0.025 \mathrm{~g} /$ 1; Fig. 2). All plants died in concentrations of $0.11 \mathrm{~g} / \mathrm{l}$. In all the treatments, roots were necrotic. At concentrations of $0.15 \mathrm{~g} / \mathrm{l}$ and above the plants had precipitations of iron on their surface, which explains the weight increase. Copper sulphate inhibited length increases at the lowest concentration of $0.6 \mathrm{mg} / \mathrm{l}$. Inhibition of weight increase and root length occurred at concentrations above $1.2 \mathrm{mg} / \mathrm{l}$ and the number of nodes was inhibited at concentrations above 1.8 mg/l (Fig. 3).

Glyphosate inhibited all the measured parameters at the lowest concentration (Fig. 4). Nevertheless, due to branch development, total length and node number increased in the 1 $\mathrm{mg} / \mathrm{l}$ concentration. Glyphosate stimulated lateral growth, inhibiting apical development in non-lethal treatments. It caused plant death at concentrations exceeding $2.5 \mathrm{mg} / \mathrm{l}$.

Total length and weight of plants exposed to the mine effluent were only affected by concentrations of $60 \%$ or more (Fig. 5). Node number and root length were always lower in the affluent that in the control conditions. In terms of $\mathrm{IC}_{50}$ (Table 3), root growth was consistently the most

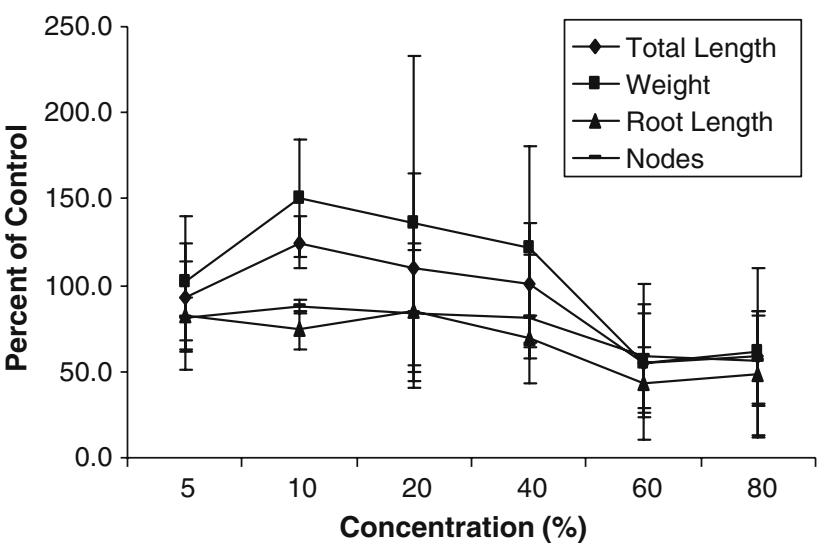

Fig. 5 Total length, weight, root length and node number of $M$. spicatum after 21 days exposition to a mining effluent. Mean and SE; $n=5$

sensitive endpoint in every test, despite the high variability among explants.

Altogether, our results showed that Myriophyllum spicatum was stimulated by low concentrations of calcium sulphate and copper. Calcium is used by plants as a component of the cell membrane and wall, and as a cofactor for several enzymes (Barceló et al. 1995). On the other hand, copper is an essential element for plant growth, since it is a component of enzymes such as tirosinase or fenolase. Copper also plays an important role in photosynthesis (Barceló et al. 1995). However, copper is also a highly effective herbicide (Guilizzoni 1991). In our case an inhibitory effect was measured at concentrations from 1.2 to $1.8 \mathrm{mg} / \mathrm{l}$ and above. Stimulatory effects, even with toxic compounds not used by plants, are known to have stimulatory effects at low concentrations occasionally (e.g., McCan et al. 2000), a situation known as hormesis.

A search of the literature reveales that $M$. spicatum has a medium sensitivity to copper sulphate; the $21 \mathrm{~d}$ $\mathrm{IC}_{50}$ values were among the least sensitive of the reported studies, but were comparable to those reported for Lemna (Table 4). However, these comparisons should be

Table 3 Concentration of the test compound that inhibited $50 \%$ of the parameter $\left(\mathrm{IC}_{50}\right)$ (and its confidence intervals) weight, length, root length and node number

\begin{tabular}{|c|c|c|c|c|c|}
\hline $\mathrm{IC}_{50}$ & Effluent (\%) & $\mathrm{CaSO}_{4}(\mathrm{~g} / \mathrm{l})$ & $\mathrm{FeSO}_{4}(\mathrm{~g} / \mathrm{l})$ & $\mathrm{CuSO}_{4}(\mathrm{mg} / \mathrm{l})$ & Glyphosate $(\mathrm{mg} / \mathrm{l})$ \\
\hline Weight & $\begin{array}{l}80.30 \\
(31-100)\end{array}$ & $\begin{array}{l}3.96 \\
(1.44-7.19)\end{array}$ & $\begin{array}{l}0.038 \\
(0.028-0.048)\end{array}$ & $\begin{array}{l}2.47 \\
(1.340-4.437)\end{array}$ & $\begin{array}{l}1.00 \\
(0.90-1.10)\end{array}$ \\
\hline Length & $\begin{array}{l}87.30 \\
(34-100)\end{array}$ & $\begin{array}{l}7.63 \\
(3.40-11.84)\end{array}$ & $\begin{array}{l}0.043 \\
(0.037-0.052)\end{array}$ & $\begin{array}{l}3.73 \\
(1.86-5.60)\end{array}$ & $\begin{array}{l}2.86 \\
(1.25-5.10)\end{array}$ \\
\hline Roots & $\begin{array}{l}69.50 \\
(40-99)\end{array}$ & $\begin{array}{l}2.24 \\
(0.64-3.84)\end{array}$ & $\begin{array}{l}0.023 \\
(0.017-0.037)\end{array}$ & $\begin{array}{l}2.19 \\
(1.024-4.682)\end{array}$ & $\begin{array}{l}0.33 \\
(0.25-0.47)\end{array}$ \\
\hline Nodes & $\begin{array}{l}89.30 \\
(60-100)\end{array}$ & - & $\begin{array}{l}0.057 \\
(0.047-0.073)\end{array}$ & $\begin{array}{l}4.49 \\
(2.70-6.74)\end{array}$ & $\begin{array}{l}5.01 \\
(1.79-4.04)\end{array}$ \\
\hline
\end{tabular}


Table 4 Summary of copper toxicity. Results are referred $\mathrm{mg} \mathrm{CuSO}_{4} / 1\left(\mathrm{mg} \mathrm{Cu}^{2+} / \mathrm{l}\right)$

\begin{tabular}{|c|c|c|c|c|c|}
\hline Organism & Group & Parameter & Method & $\begin{array}{l}\mathrm{mg} \mathrm{l}^{-1} \\
\mathrm{CuSO}_{4}\left(\mathrm{Cu}^{2+}\right)\end{array}$ & Author \\
\hline \multirow[t]{3}{*}{ Myriophyllum spicatum } & Macro & Weight & $21 \mathrm{~d}-\mathrm{IC}_{50}$ & $2.47(0.98)$ & $\mathrm{a}$ \\
\hline & Macro & Shoot length & $21 \mathrm{~d}-\mathrm{IC}_{50}$ & $3.73(1.48)$ & $\mathrm{a}$ \\
\hline & Macro & Root length & $21 \mathrm{~d}-\mathrm{IC}_{50}$ & $2.19(0.87)$ & $\mathrm{a}$ \\
\hline \multirow[t]{2}{*}{ Lemna minor } & Macro & Root length & $20 \mathrm{~d}-\mathrm{EC}_{50}$ & $(0.037)$ & $\mathrm{b}$ \\
\hline & Macro & Biomass & $5 \mathrm{~d}-\mathrm{EC}_{50}$ & $2.3(0.92)$ & $\mathrm{c}$ \\
\hline Elodea canadiensis & Macro & $\mathrm{O}_{2}$ production & $10 \mathrm{~d}-\mathrm{EC}_{50}$ & $(0.040)$ & $\mathrm{b}$ \\
\hline Sinapsis alba & Other & Root length & $8 \mathrm{~d}-\mathrm{IC}_{50}$ & $(4.3)$ & $\mathrm{d}$ \\
\hline Chlamydomonas & Algae & Growth & $72 \mathrm{~h}-\mathrm{EC}_{50}$ & $(0.079)$ & $\mathrm{b}$ \\
\hline \multirow[t]{2}{*}{ reinhardi } & Algae & Growth & $96 \mathrm{~h}-\mathrm{EC}_{50}$ & $(0.047)$ & $\mathrm{b}$ \\
\hline & Algae & Growth & $10 \mathrm{~d}-\mathrm{EC}_{50}$ & $(0.032)$ & $\mathrm{b}$ \\
\hline Scenedesmus subspicatus & Algae & Growth & $72 \mathrm{~h}-\mathrm{EC}_{50}$ & $(0.12)$ & $\mathrm{b}$ \\
\hline \multirow[t]{2}{*}{ Euglena gracilis } & Algae & Growth & $72 \mathrm{~h}-\mathrm{EC}_{50}$ & (18) & $\mathrm{b}$ \\
\hline & Algae & Growth & $5 \mathrm{~d}-\mathrm{EC}_{50}$ & $(7.9)$ & $\mathrm{b}$ \\
\hline \multirow[t]{2}{*}{ Selenastrum capricornutum } & Algae & Growth & $4 \mathrm{~d}-\mathrm{EC}_{50}$ & $(0.008)$ & $\mathrm{e}$ \\
\hline & Algae & Growth & $5 \mathrm{~d}-\mathrm{EC}_{50}$ & $0.031(0.012)$ & $\mathrm{c}$ \\
\hline Skeletonema costatum & Algae & Growth & $5 \mathrm{~d}-\mathrm{EC}_{50}$ & $0.25(0.995)$ & $\mathrm{c}$ \\
\hline \multirow[t]{2}{*}{ Tethahymena pyriformis } & Protoz & Growth & $48 \mathrm{~h}-\mathrm{EC}_{50}$ & $(8.0)$ & $\mathrm{b}$ \\
\hline & Protoz & Growth & $96 \mathrm{~h}-\mathrm{EC}_{50}$ & $(10)$ & $\mathrm{b}$ \\
\hline Hydra vulgari & Protoz & Mortality & $96 \mathrm{~h}-\mathrm{LC}_{50}$ & $(0.056)$ & f \\
\hline Hydra oligartis & Protoz & Mortality & $96 \mathrm{~h}-\mathrm{LC}_{50}$ & $(0.084)$ & f \\
\hline Hydra viridissima & Protoz & Mortality & $96 \mathrm{~h}-\mathrm{LC}_{50}$ & $(0.025)$ & $\mathrm{f}$ \\
\hline Cambarus robustus & Crust & - & $24 \mathrm{~h}-\mathrm{LC}_{50}$ & $(3.48)$ & $\mathrm{g}$ \\
\hline \multirow[t]{2}{*}{ Gammarus pulex } & Crust & Mortality & $48 \mathrm{~h}-\mathrm{LC}_{50}$ & $(0.047)$ & $\mathrm{b}$ \\
\hline & Crust & Mortality & $10 \mathrm{~d}-\mathrm{LC}_{50}$ & $(0.033)$ & $\mathrm{b}$ \\
\hline Ceriodaphnia $s p$ & Crust & Mortality & $48 \mathrm{~h}-\mathrm{LC}_{50}$ & $(0.035)$ & e \\
\hline Orconectes rusticus & Crust & - & $24 \mathrm{~h}-\mathrm{LC}_{50}$ & $(2.5)$ & $\mathrm{g}$ \\
\hline Daphnia magna & Crust & Immobility & $48 \mathrm{~h}-\mathrm{EC}_{50}$ & $0.18(0.072)$ & $\mathrm{c}$ \\
\hline \multirow[t]{3}{*}{ Chironomus riparius } & Dipt & Mortality & $48 \mathrm{~h}-\mathrm{LC}_{50}$ & $(1.2)$ & $\mathrm{b}$ \\
\hline & Dipt & Mortality & $96 \mathrm{~h}-\mathrm{LC}_{50}$ & $(0.70)$ & $\mathrm{b}$ \\
\hline & Dipt & Mortality & $10 \mathrm{~d}-\mathrm{LC}_{50}$ & $(0.20)$ & $\mathrm{b}$ \\
\hline \multirow[t]{2}{*}{ Brachionus calyciflorus } & Rotif & Mortality & $24 \mathrm{~h}-\mathrm{LC}_{50}$ & $(0.026)$ & $\mathrm{b}$ \\
\hline & Rotif & Feeding & $5 \mathrm{~h}-\mathrm{EC}_{50}$ & $(0.033)$ & $\mathrm{b}$ \\
\hline Lepomis macrochirus & Fish & Mortality & $96 \mathrm{~h}-\mathrm{LC}_{50}$ & $0.892(0.355)$ & $\mathrm{c}$ \\
\hline
\end{tabular}

(When more than one experiment is reported by a same author, only the lowest and highest values are indicated. Macro = macrophyte; Protoz = protozoa; Crus = crustacean; Dip = diptera; Rotif = rotifera. References: (a) Present work; (b) Girling et al., 2000; (c) Environmental Fate and Effects Division. US EPA, Washington, DC, 2000; (d) Fargašová et al., 1998; (e) Deanovic et al., 1999; (f) Karntanut and Pascoe, 2002; (g) Sherba et al., 2000)

interpreted with caution because of differences in methodology. For instance, in our case and in the EPA report the tests were run with culture media, whereas Guirling et al. (2002) worked on mesocosms. M. spicatum was revealed by our tests to be me most sensitive testing organism for glyphosate (see Table 5 for a comparison with the literature).
Our data suggests that $M$. spicatum could be very sensitive to some pollutants, especially herbicides. This species has great potential to be used in toxicological assays because of its sensitivity, its easy culture in the laboratory and its consistent growth among explants. As with other plants, root growth was a suitable endpoint, but showed high variability among explants. 
Table 5 Summary of glyphosate toxicity (mg active ingredient/l)

\begin{tabular}{|c|c|c|c|c|c|}
\hline \multirow{2}{*}{$\begin{array}{l}\text { Organism } \\
\text { Myriophyllum spicatum }\end{array}$} & \multirow[b]{2}{*}{ Macro } & \multirow{2}{*}{$\begin{array}{l}\text { Parameter } \\
\text { Weight }\end{array}$} & \multicolumn{2}{|c|}{ Concentration $\mathrm{mgl}^{-1}$} & \multirow{2}{*}{$\begin{array}{l}\text { Author } \\
\mathrm{a}\end{array}$} \\
\hline & & & $21 \mathrm{~d}-\mathrm{IC}_{50}$ & 1.00 & \\
\hline & & Shoot length & $21 d-\mathrm{IC}_{50}$ & 2.86 & $\mathrm{a}$ \\
\hline & & Root length & $21 \mathrm{~d}-\mathrm{IC}_{50}$ & 0.33 & $\mathrm{a}$ \\
\hline & & Shoot number & $5 \mathrm{~d}-\mathrm{EC}_{50}$ & 1.6 & $\mathrm{~b}$ \\
\hline \multirow[t]{3}{*}{ Myriophyllum sibiricum } & Macro & Shoot length & $14 \mathrm{~d}-\mathrm{EC}_{50}$ & 28.79 & $\mathrm{c}$ \\
\hline & & Root number & $14 \mathrm{~d}-\mathrm{EC}_{50}$ & 3.35 & $\mathrm{c}$ \\
\hline & & Root length & $14 \mathrm{~d}-\mathrm{EC}_{50}$ & 1.22 & $\mathrm{c}$ \\
\hline Lemna gibba & Macro & Biomass & $14 \mathrm{~d}-\mathrm{EC}_{50}$ & 21.5 & $\mathrm{~d}$ \\
\hline Lemna minor & Macro & Biomass & $48 \mathrm{~h}-\mathrm{EC}_{50}$ & $2-16.91$ & $\mathrm{~d}$ \\
\hline \multirow[t]{2}{*}{ Selenastrum capricornutum } & Algae & Biomass & $96 \mathrm{~h}-\mathrm{EC}_{50}$ & 5.81 & $\mathrm{e}$ \\
\hline & & Biomass & $7 \mathrm{~d}-\mathrm{EC}_{50}$ & 12.54 & $\mathrm{~d}$ \\
\hline \multirow[t]{2}{*}{ Skeletonema costatum } & Algae & Biomass & $96 \mathrm{~h}-\mathrm{EC}_{50}$ & 1.85 & $\mathrm{e}$ \\
\hline & & Biomass & $7 \mathrm{~d}-\mathrm{EC}_{50}$ & 0.77 & $\mathrm{~d}$ \\
\hline Anabaena flosaquae & Algae & Biomass & $7 \mathrm{~d}-\mathrm{EC}_{50}$ & 38.5 & $\mathrm{~d}$ \\
\hline Tethahymena pyriformis & Protoz & Biomass & $40 \mathrm{~h}-\mathrm{EC}_{50}$ & 29.5 & $\mathrm{e}$ \\
\hline Euplotes vannus & Protoz & Biomass & $48 \mathrm{~h}-\mathrm{EC}_{50}$ & 23.5 & $\mathrm{e}$ \\
\hline \multirow[t]{4}{*}{ Daphnia magna } & Crust & Immobility & $48 \mathrm{~h}-\mathrm{EC}_{50}$ & 61.72 & $\mathrm{f}$ \\
\hline & & Immobility & $48 \mathrm{~h}-\mathrm{EC}_{50}$ & $24-42$ & $\mathrm{f}$ \\
\hline & & Immobility & $48 \mathrm{~h}-\mathrm{EC}_{50}$ & 3 & $\mathrm{~d}$ \\
\hline & & Immobility & $48 \mathrm{~h}-\mathrm{EC}_{50}$ & $5.3-310$ & $\mathrm{~d}$ \\
\hline Daphnia spinulata & Crust & Immobility & $48 \mathrm{~h}-\mathrm{EC}_{50}$ & 66.18 & $\mathrm{f}$ \\
\hline \multirow[t]{3}{*}{ Daphnia pulex } & Crust & Immobility & $48 \mathrm{~h}-\mathrm{EC}_{50}$ & 7.9 & $\mathrm{f}$ \\
\hline & & Immobility & $96 \mathrm{~h}-\mathrm{EC}_{50}$ & 25.5 & $\mathrm{f}$ \\
\hline & & Immobility & $48 \mathrm{~h}-\mathrm{EC}_{50}$ & $7.9-242$ & $\mathrm{~d}$ \\
\hline Ceriodaphnia dubia & Crust & Mortality & $48 \mathrm{~h}-\mathrm{LC}_{50}$ & 5.39 & $\mathrm{e}$ \\
\hline Arcartia tonsa & Crust & Mortality & $48 \mathrm{~h}-\mathrm{LC}_{50}$ & 1.77 & $\mathrm{e}$ \\
\hline Gammarus & Crust & Mortality & $96 \mathrm{~h}-\mathrm{LC}_{50}$ & 42 & $\mathrm{~d}$ \\
\hline \multicolumn{6}{|l|}{ pseudolimnaeus } \\
\hline \multirow[t]{2}{*}{ Chironomus plumosus } & Dipt & Mortality & $48 \mathrm{~h}-\mathrm{LC}_{50}$ & 18 & $\mathrm{~d}$ \\
\hline & & Mortality & $48 \mathrm{~h}-\mathrm{LC}_{50}$ & 55 & $\mathrm{~d}$ \\
\hline Crassotrea virginica & Moll & Mortality & $48 \mathrm{~h}-\mathrm{LC}_{50}$ & 10 & $\mathrm{~d}$ \\
\hline Ictalurus punctatus & Fish & Mortality & $96 \mathrm{~h}-\mathrm{LC}_{50}$ & $13-16$ & $\mathrm{~d}$ \\
\hline Lepomis macrochirus & Fish & Mortality & $96 \mathrm{~h}-\mathrm{LC}_{50}$ & $5.8-140$ & $\mathrm{~d}$ \\
\hline Pimephales promelas & Fish & Mortality & $96 \mathrm{~h}-\mathrm{LC}_{50}$ & 9.4 & $\mathrm{~d}$ \\
\hline
\end{tabular}

(When more than one experiment is reported by a same author, only the lowest and highest values are indicated. Macro = macrophyte; Protoz = protozoa; Crus = crustacean; Dip = diptera; Rotif = rotifera; Moll = mollusca. References: (a) Present work; (b) Bird, 1993; (c) Roshon et al., 1999; (d) Environmental Fate and Effects Division. US EPA, Washington, DC, 2000; (e) Tsui \& Chu, 2003; (6) Alberdi et al., 1996)

Acknowledgments The technical assistance of Mrs. Maria Ludovina Lopes is gratefully acknowledged. This research was founded by the IMAR, the Institute of Marine Sciences and the IAV, Institute of Environment and Life.

\section{References}

Alberdi JL, Sáenz ME, Dimarzio WD, Tortorelli MC (1996) Comparative acute toxicity of two herbicides, paraquat and glyphosate, to Daphnia magna and D. spinulata. Bull Environ Contam Toxicol 57:229-235
American Society for Testing and Materials (2000) E 1913-97. Standard guide for conducting static, axenic, 14-day phytotoxicity tests in test tubes with the submersed aquatic macrophytes Myriophyllum sibiricum Komarov

Barceló J, Nicolás G, Sabater B, Sánchez R (1995) Fisiología Vegetal. Pirámide. Madrid. $662 \mathrm{pp}$

Bird KT (1993) Comparison of herbicide toxicity using in vitro cultures of Myriophyllum spicatum. J Aquat Plant Management 31:43-45

Coimbra CN, Graça MAS, Cortes RM (1996) The effects of a basic effluent on macroinvertebrate community structure in a temporary Mediterranean river. Environ Pollut 94:301-307 
Fargašová A (1998) Root growth inhibition, photosynthetic pigments production, and metal accumulation in Sinapis alba as the parameters for trace metals effect determination. Bull Environ Contam Toxicol 61:762-769

Ferreira RCF, Graça MAS (2002) A comparative study of the sensitivity of selected plants to mining effluents. Limnetica 21:129-134

Guilizzoni P (1991) The role of heavy metals and toxic materials in the physiological ecology of submersed macrophytes. Aquat Bot 41:87-109

Hanson ML, Sibley PK, Mabury SA, Muir DC, Solomon KR (2003) Field level evaluation and risk assessment of the toxicity of dichloroacetic acid to the aquatic macrophytes Lemna gibba, Myriophyllum spicatum, and Myriophyllum sibiricum. Ecotoxicol Environ Safety 55:46-63

Guirling AE, Pascoe D, Janssen CR, Peither A, Wenzel A, Schäfer H, Neumeier B, Mitchell GC, Taylor EJ, Maund SD, Lay JP, Jüttner I, Crossland NO, Stephenson RR, Persoone G (2000) Development of methods for evaluating toxicity to freshwater ecosystems. Ecotoxicol Environ Safety 45:148-176
Karntanut W, Pascoe D (2002) The toxicity of copper, cadmium and zinc to four different Hydra (Cnidaria: Hydrozoa). Chemosphere 47:1059-1064

Roshon RD, McCann JH, Thompson DG, Stephenson GR (1999) Effects of seven forestry management herbicides on Myriophyllum sibiricum, as compared with other nontarget aquatic organisms. Can J Forest Res 29:1158-1169

Sherba M, Dunham DW, Harvey HH (2000) Sublethal copper toxicity and food response in the freshwater crayfish Cambarus bartonii (Cambaridae, Decapoda, Crustacea). Ecotoxicol Environ Safety 46:329-333

Tsui MTK, Chu LM (2003) Aquatic toxicity of glyphosate-based formulations: comparison between different organisms and the effects of environmental factors. Chemosphere 52:1189 1197

Wang TC, Weissmean JC, Ramesh G, Varadarajan R, Benemann JR (1996) Parameter for removal of toxic heavy metals by water milfoil (M.spicatum). Bull Environ Contam Toxicol 57: 779-786 